\title{
Aktivitas Antifungi Ekstrak Etanol Daun Eryngium foetidum L. Terhadap Pertumbuhan Xeromyces sp. secara in vitro
}

\author{
Ines S Simatupang ${ }^{1}$, Elvi Rusmiyanto PW ${ }^{1}$, Rikhsan Kurniatuhadi ${ }^{1}$ \\ ${ }^{1}$ Program Studi Biologi, Fakultas MIPA, Universitas Tanjungpura, JL. Prof. Dr. H. Hadari Nawawi, Pontianak \\ Email: inessimatupang@gmail.com
}

\begin{abstract}
Eryngium foetidum is a plant commonly used a seasoning cuisine and has a variety of chemical compounds that potentially an antifungal. The ethanol extract Eryngium foetidum was tested against fungal isolate Xi.01. The isolat Xi.01 isolated from the pepper (Piper Nigrum) stem was identified as Xeromyces sp. This study aimed to determine the ability of the antifungal ethanol extract of Eryngium foetidum against Xeromyces sp. (Xi.01). This study used solid dilution method and completely randomized design using 18 treatments, i.e negative control, positive control, diethanolamide concentration of $2.5 ; 5 ; 7.5$ and $10 \%$ combined with the ethanol extract concentration of Eryngium foetidum of 5; 10; 20 and 40\%. The results showed 16 treatment combinations had the same low antifungal activity level in the range $13,59-22,40 \%$.
\end{abstract}

Key word: antifungal, combination, Eryngium foetidum, ethanol extract, Xeromyces sp.

\section{PENDAHULUAN}

Eryngium foetidum merupakan tanaman herba biannual yang tumbuh di daerah tropis. Tanaman ini dikenal sebagai ketumbar jawa di Malaysia, dan daun sup Dayak di Kalimantan Barat. Eryngium foetidum sangat umum digunakan dalam berbagai kuliner seperti salad, sup, saus, mi, dan hidangan laut (Ignacimuthu et al., 1999). Selain digunakan sebagai bahan masakan Eryngium foetidum juga sering digunakan sebagai obat tradisional. Berdasarkan Shavandi et al., (2012), Eryngium foetidum digunakan untuk mengobati luka bakar, sakit telinga, demam, hipertensi, konstipasi, asma, sakit perut, gigitan ular, artritis, diare dan malaria.

Berdasarkan penelitian Bhavana et al., (2013) Eryngium foetidum mengandung fenol, flavonoid dan tanin yang dikenal memiliki aktivitas biologi seperti anti-inflamasi, antibakteri, antioksidan, dan antikanker. Berdasarkan hasil riset Chowdhury et al., (2007) diketahui Eryngium foetidum mengandung 63 senyawa kimia diantaranya camphenol, limonene, myrcene, $\alpha$-pinene, $\beta$-pinene, $O$-cymene, senyawa yang sama juga ditemukan pada buah pala yang berfungsi sebagai antijamur (Sipahelut, 2015). Oleh karena itu, kandungan kimia yang terdapat pada Eryngium foetidum berpotensi sebagai biopestisida untuk mengendalikan jamur patogen. Namun menurut Indrawijaya (2016), biopestisida masih memiliki formulasi yang sangat sederhana sehingga diperlukan bahan aditif untuk meningkatkan efektivitas pestisida seperti yang umum digunakan pada pestisida sintetik seperti dietanolamida (DEA).

Dietanolamida (DEA) merupakan bahan aditif yang tergolong surfaktan non-ionik dan bersifat ramah lingkungan. DEA berperan dalam mendispersikan, menghomogenkan, meratakan dan merekatkan bahan aktif dan aditif lainnya dengan media pembawanya sehingga sangat berpotensi meningkatkan efektivitas pestisida (Indrawijaya, 2016). Jika dilarutkan ke dalam pelarut pada konsentrasi rendah, surfaktan DEA akan memiliki kemampuan untuk menempatkan diri pada antar muka dua jenis media yang tidak larut sehingga kedua media tersebut dapat larut. (Georgou et al., 1992; Hui 1996).

Berdasarkan kandungan kimia Eryngium foetidum dan kemampuan dietanolamida sebagai pelarut, perlu untuk dilakukan penelitian dengan mengkombinasikan varian konsentrasi ekstrak etanol daun Eryngium foetidum dan varian konsentrasi DEA sebagai pelarut dan bahan aditif guna meningkatkan efektivitas ekstrak sehingga mempengaruhi pertumbuhan jamur Xeromyces sp.

\section{BAHAN DAN METODE}

Waktu dan Tempat Penelitian

Penelitian ini telah dilaksanakan selama tiga bulan yaitu pada bulan Agustus sampai Oktober Penelitian 2018. Pengambilan sampel daun 
Eryngium foetidum dilakukan di Desa Pelaik Kecamatan Teriak Kabupaten Bengkayang dan pangkal batang lada busuk dilakukan di Desa Suti Semarang Kecamatan Suti Semarang Kabupaten Bengkayang. Isolasi jamur Xeromyces sp. serta uji aktivitas ekstrak dilakukan di Laboratorium Jamur Balai Proteksi Tanaman Perkebunan, Pontianak. Ekstraksi daun Eryngium foetidum dilakukan di Laboratorium Biokimia Poli-teknik Negeri Pontianak

\begin{abstract}
Alat
Alat yang digunakan dalam penelitian ini adalah alumunium foil, autoklaf, blender, bunsen, cawan petri, cutter, erlenmeyer, rotary evaporator, gelas ukur, gunting, hot plate, inkubator, jarum ose, kapas, kertas label, kertas merang, mikroskop, pinset, plastik wayang, plastik wrap, pisau, timbangan, tisu
\end{abstract}

\section{Bahan}

Bahan yang digunakan dalam penelitian ini adalah alkohol, asam laktat, akuades steril, etanol, chlorox, daun Eryngium foetidum, dithane, media biakan PDA, spiritus dan surfaktan DEA

\section{Prosedur Kerja}

\section{Pengambilan Sampel}

Pengambilan sampel daun Eryngium foetidum dilakukan dengan melihat ciri daun yang sehat. Daun yang diambil adalah daun yang berwarna hijau, tidak terdapat bercak

penyakit atau mengalami kerusakan (Gunawan et al., 2010).

\section{Sterilisasi Alat}

Alat-alat tahan panas yang akan disterilisasi dicuci bersih kemudian dikeringanginkan. Setelah kering dibungkus dengan kertas merang dan plastik tahan panas kemudian disterilisasi menggunakan autoklaf pada suhu $121^{\circ} \mathrm{C}$, tekanan $1 \mathrm{~atm}$ selama 15 menit.

\section{Pembuatan Media}

Media PDA sebanyak 39 gr disuspensikan dalam 1 liter air dan dipanaskan keatas hot plate dan diaduk menggunakan magnetic stirer hingga mendidih. Media dituang didalam erlenmeyer dan disumbat dengan kapas, disterilkan menggunakan autoklaf pada suhu $121^{\circ} \mathrm{C}$ dengan tekanan 1 atm selama 15 menit (Nugroho, 2010).

\section{Pembuatan Simplisia}

Daun Eryngium foetidum sebanyak $4 \mathrm{~kg}$ dicuci bersih kemudian dikeringanginkan sampai kadar airnya hilang. Daun yang telah kering diblender hingga halus dan diletakkan dalam wadah dan disimpan.

\section{Pembuatan Ekstrak}

Pembuatan ekstrak Eryngium foetidum menggunakan pelarut etanol dilakukan dengan metode maserasi simplisia perbandingan 1:2 (w/v). Simplisia halus sebanyak $500 \mathrm{~g}$ direndam dalam $1000 \mathrm{ml}$ etanol selama $48 \mathrm{jam}$. Hasil rendaman yang telah disaring kemudian dievaporasi dengan alat rotary evaporator sampai semua pelarut menguap. Ekstrak pekat yang diperoleh ditimbang dan disimpan dalam desikator (Hutasoit et al., 2013).

\section{Pengenceran Ekstrak dan Formulasi Dietanolamida}

Dietanolamida sebanyak 0,$25 ; 0,5 ; 0,75$ dan 1 dilarutkan dalam $10 \mathrm{ml}$ akuades steril untuk membuat fomula larutan dengan konsentrasi 2,5; 5; 7,5 dan $10 \%$. Sebanyak 0,5; 1; 2 dan 4gr ekstrak E. foetidum dilarutkan dalam larutan DEA 2,5; 5; 7,5 dan $10 \%$. untuk membuat larutan dengan konsentrasi $5 ; 10 ; 20$ dan $40 \%$.

\section{Pengujian Aktivitas Antifungi}

Pengujian aktivitas antifungi menggunakan metode dilusi padat, yaitu dengan cara mencampurkan ekstrak dengan media agar (Fitriani et al., 2013). Konsentrasi ekstrak yang diuji adalah 5; 10; 20 dan $40 \%$ masing-masing dilarutkan dalam DEA 2,5; 5; 7,5 dan $10 \%$. Masing-masing kombinasi perlakuan diambil $1 \mathrm{ml}$ dan dicampur dengan $19 \mathrm{ml}$ media PDA dan dibiarkan memadat. Hifa isolat jamur Xeromyces sp. diinokulasikan pada media yang telah padat dengan metode tusuk tepat ditengah cawan petri. Hifa diinokulasi juga pada media tanpa ekstrak sebagai kontrol negatif dan dithane $1 \%$ sebagai kontrol positif. Biakan yang telah diinokulasi diinkubasi pada suhu $25^{0} \mathrm{C}$ selama 7 hari (Oktaviana, et al., 2017).

\section{Parameter Pengamatan}

Parameter yang diamati pada penelitian ini adalah diameter koloni jamur dan persentase daya hambat dari setiap perlakuan. Pengukuran diameter jamur dilakukan dengan menggunakan jangka sorong secara vertikal, horizontal dan diagonal. Hasil pengukuran dinyatakan dalam satuan milimeter (mm) (Yanti et al., 2016).

Menurut Rai (2006) persentase daya hambat pertumbuhan jamur dapat dihitung menggunakan rumus sebagai berikut : 
$\mathrm{P}=\frac{\mathrm{D} 1-\mathrm{D} 2}{\mathrm{D} 1} \times 100 \%$

Keterangan :

P : Persentase daya hambat

D1 : Diameter koloni kontrol

D2 : Diameter koloni perlakuan

Nilai dari persentase aktivitas antifungi dapat dilihat pada tabel 1 .

Tabel 1. Klasifikasi Aktivitas Antifungi

\begin{tabular}{ll}
\hline Aktivitas Antifungi & Tingkat Aktivitas \\
\hline AFA $\geq 75 \%$ & Sangat kuat \\
$75 \% \leq \mathrm{AFA} \geq 50 \%$ & Kuat \\
$50 \% \leq \mathrm{AFA} \geq 25 \%$ & Sedang \\
$25 \% \leq \mathrm{AFA}<0$ & Lemah \\
0 & Tidak aktif \\
\hline
\end{tabular}

Sumber: Mori et al., 1997

\section{Analisis Data}

Data daya hambat ekstrak Eryngium foetidum terhadap koloni Xeromyces sp. dianalisis menggunakan Anova. Jika kombinasi perlakuan menunjukkan pengaruh yang signifikan, maka analisis dilanjutkan dengan uji Duncan pada taraf uji $5 \%$. Pengolahan data menggunakan bantuan program SPSS 23.

\section{HASIL DAN PEMBAHASAN \\ Hasil}

Aktivitas antifungi ekstrak Eryngium foetidum terhadap pertumbuhan koloni jamur isolat anggota spesies Xeromyces sp. (Xi.01) diketahui dari rerata diameter koloni jamur hari ke 7 pada masingmasing perlakuan yang diujikan. Hasil analisis menggunakan anova menunjukkan ekstrak Eryngium foetidum dan dietanolamida tidak berpengaruh nyata terhadap pertumbuhan Xeromyces sp. $\left(\mathrm{F}_{17,36}=1,951 ; \mathrm{p}=0,107 ;\right.$ Anova $)$ (Tabel 2)

Tabel 2. Rerata Diameter Koloni Jamur Xeromyces sp. (Xi.01) dan Persentase Aktivitas Antifungi Eryngium foetidum

\begin{tabular}{llll}
\hline Perlakuan & $\begin{array}{l}\text { Rerata Diameter } \\
\text { Koloni Jamur }(\mathrm{mm})\end{array}$ & $\begin{array}{l}\text { Persentase Aktivitas } \\
\text { Antifungi }(\%)\end{array}$ & Tingkat Aktivitas \\
\hline K- & $79,08 \pm 1,58$ & - & - \\
DEA 2,5\% + Ek 5\% & $68,33 \pm 8,74$ & 13,59 & Lemah \\
DEA 2,5\% + Ek 10\% & $62,46 \pm 6,19$ & 17,56 & Lemah \\
DEA 2,5\% + Ek 20\% & $70,89 \pm 1,6$ & 10,35 & Lemah \\
DEA 2,5\% + Ek 40\% & $64,06 \pm 2,8$ & 18,99 & Lemah \\
DEA 5\% + Ek 5\% & $64,36 \pm 10,2$ & 18,61 & Lemah \\
DEA 5\% + Ek 10\% & $64,74 \pm 6,57$ & 18,12 & Lemah \\
DEA 5\% + Ek 20\% & $65,97 \pm 5,99$ & 16,57 & Lemah \\
DEA 5\% + Ek 40\% & $64,34 \pm 2,23$ & 18,64 & Lemah \\
DEA 7,5\% + Ek 5\% & $66,81 \pm 3,64$ & 15,50 & Lemah \\
DEA 7,5\% + Ek 10\% & $64,08 \pm 1,83$ & 18,96 & Lemah \\
DEA 7,5\% + Ek 20\% & $66,41 \pm 1,15$ & 16,01 & Lemah \\
DEA 7,5\% + Ek 40\% & $62,96 \pm 5,54$ & 20,37 & Lemah \\
DEA 10\%+ Ek 5\% & $61,36 \pm 8,9$ & 22,40 & Lemah \\
DEA 10\% + Ek 10\% & $62,47 \pm 3,7$ & 20.99 & Lemah \\
DEA 10\%+ Ek 20\% & $66,3 \pm 7,96$ & 16,16 & Lemah \\
DEA 10\% + Ek 40\% & $66,48 \pm 1,34$ & 15,93 & Kuat \\
K+ & $38,13 \pm 2,09$ & 51,78 & \\
\hline Ke
\end{tabular}

Keterangan:

DEA : dietanolamida

Ek : ekstrak

K- $\quad$ : kontrol negatif

$\mathrm{K}+\quad$ : kontrol positif 


\section{Pembahasan}

Penelitian ini menggunakan etanol $96 \%$ sebagai pelarut ekstraksi Eryngium foetidum Etanol dipilih sebagai pelarut karena tingkat toksisitasnya rendah dan hasil ekstraksinya tinggi. Etanol mampu menarik senyawa bermolekul rendah seperti saponin dan flavonoid sehingga mampu menghasilkan ekstrak yang lebih baik sebagai antimikroba. Etanol dengan konsentrasi yang lebih besar akan mempermudah pemisahan senyawa metabolit sekunder dari pelarut sehingga pada penelitian ini menggunakan etanol 96\% (Syukriah et al., 2014).

Hasil uji (Tabel 2) menunjukkan tidak ada perbedaan nyata pada diameter jamur disetiap perlakuan, hal ini diduga karena konsentrasi yang digunakan kecil sehingga tidak menyebabkan perubahan sistem fisiologis jamur yang dapat menyebabkan jamur terhambat pertumbuhannya. Berdasarkan Chowdhury et al., (2007) Eryngium foetidum diidentifikasi memiliki 63 senyawa kimia dan diantaranya terdapat camphenol, limonene, myrcene, $\alpha$-pinene, $\beta$-pinene, dan $O$-cymene yang diduga bersifat antifungi namun memiliki persentase yang sangat kecil dalam daun Eryngium foetidum sehingga diduga belum mampu menghambat pertumbuhan jamur Xeromyces.

Penelitian ini menggunakan dietanolamida sebagai pelarut ekstrak Eryngium foetidum agar dapat tercampur dengan media PDA. Dietanolamida pada konsentrasi 2,$5 ; 5 ; 7,5$ dan $10 \%$ tidak memberikan pengaruh signifikan terhadap ekstrak Eryngium foetidum dalam menghambat pertumbuhan Xeromyces sp. Hal ini dikarenakan dietanolamida merupakan pelarut yang tidak bersifat toksik tetapi meningkatkan efektivitas dari ekstrak yang diikat dietanolamida (Indrawijaya, 2016). Kandungan senyawa antifungi ekstrak Eryngium foetidum yang sedikit menyebabkan senyawa antifungi yang diikat oleh dietanolamida tidak cukup untuk menghambat pertumbuhan Xeromyces sp.

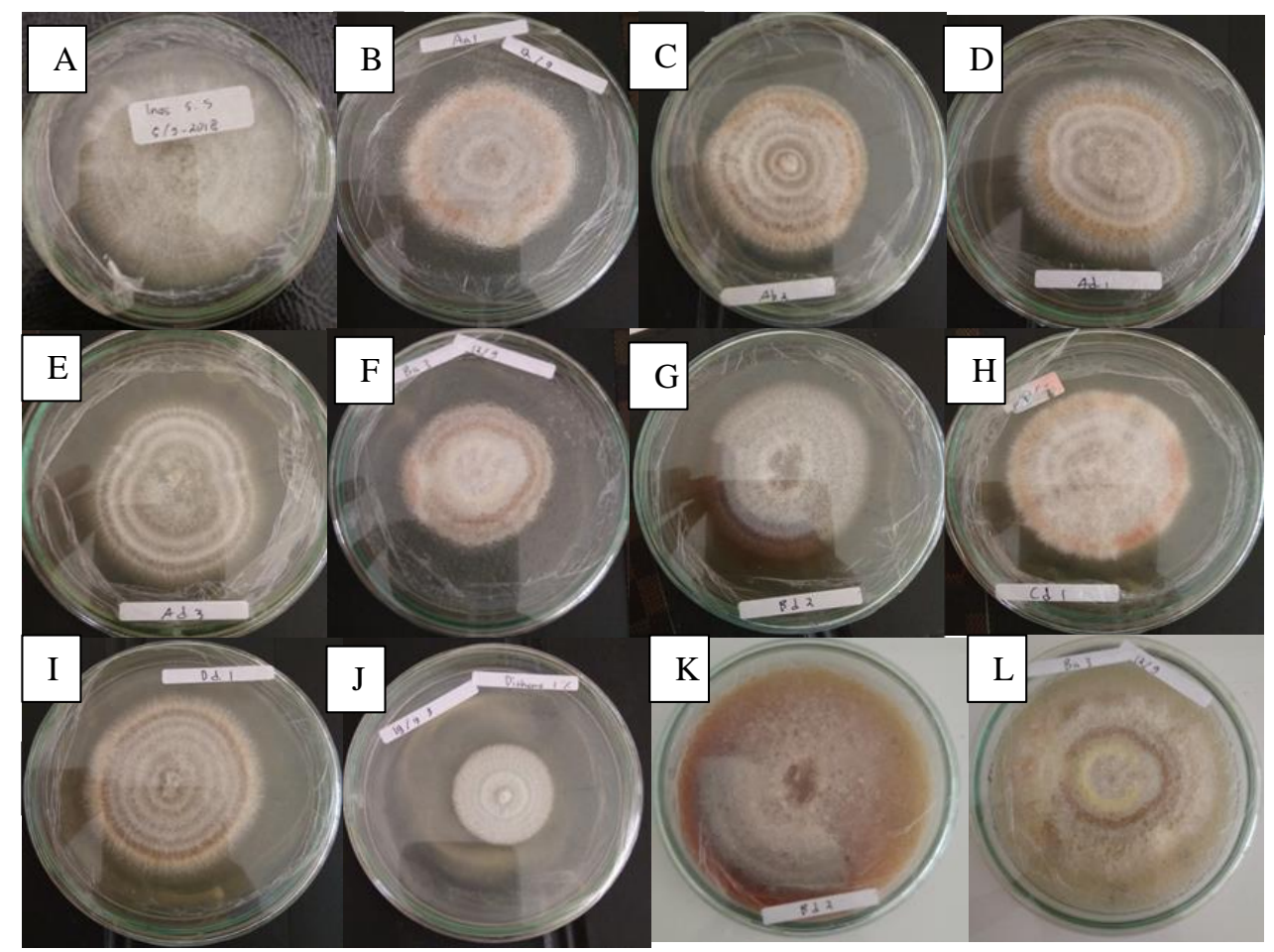

Gambar 1. Pertumbuhan koloni Xeromyces sp. Isolat Xi.01 setelah 7 hari perlakuan. Keterangan: A. Kontrol negatif; B. Konsentrasi 5\% dalam DEA 2,5\%; C. Konsentrasi 10\% dalam DEA 2,5\%; D \& E, Konsentrasi 40\% dalam DEA 2,5\%; F. Konsentrasi 5\% dalam DEA 5\%; G. Konsentrasi 40\% dalam DEA 5\%; H. Konsentrasi 40\% dalam DEA 7,5\%; I. Konsentrasi 40\% dalam DEA 10\%; J. Dithane 1\%; K. Konsentasi 40\% dalam DEA 5\% (koloni berumur 13 hari); L. Konsentrasi 5\% dalam DEA 5\% (koloni berumur 12 hari) 
Hasil yang ditunjukkan pada gambar 1 memperlihatkan jamur yang diberi ekstrak menghasilkan pigmen berwarna merah bata. Menurut Gmoser et al., (2017) pigmen jamur umumnya diproduksi di sitoplasma sel sebagai respon dari kondisi lingkungan yang tidak menguntungkan dan kurangnya nutrisi. Pigmen berwarna merah yang dihasilkan Xeromyces sp. (Xi.01) tergolong ke dalam pigmen karotenoid yaitu pigmen yang bersifat hidrophobik dan sangat umum ditemukan pada anggota genus Monascus. Pigmen karotenoid memiliki fungsi ekologi bagi jamur yaitu sebagai pelindung fotooksidasi dan kandungan karotenoid berupa astaxanthin dan canthaxanthin yang dapat berakumulasi untuk merespon lingkungan yang tidak menguntungkan. Hal ini menunjukkan bahwa selain sedikitnya kandungan senyawa antifungi ekstrak Eryngium foetidum, jamur Xeromyces sp. juga memiliki mekanisme pertahanan terhadap senyawa-senyawa antifungi yang dapat menghambat pertumbuhannya.

Xeromyces sp. merupakan jamur yang dapat bertahan pada kondisi lingkungan yang kurang menguntungkan. Berdasarkan penelitian Sari et al., (2014), saran dosis dithane yang digunakan adalah 1,5 - 3,0 gr/l dapat menghambat pertumbuhan jamur namun isolat jamur Xeromyces sp. (Xi.01) masih dapat bertahan hidup pada konsentrasi dithane $10 \mathrm{gr} / \mathrm{l}$.

\section{DAFTAR PUSTAKA}

Bhavana, GP, Chandrika, R and Saraswathi, KJ. 2013, Quantitative determination of secondary compounds in populations of Eryngium foetidum $\mathrm{L}$. from India. INT J CURR SCI 2013, 9: E 24-28

Chowdhury, JU, Nandi, NC \& Yusuf, M, 2007, Chemical Constituents of Essential Oil of the Leaves of Eryngium foetidum from Bangladesh. Bangladesh J. Sci. Ind. Res, Vol 42, Hal 3

Cowan, M M. 1999. Plant Product As Antimicrobial Agents. Clinical Microbiology Reviews, Vol. 12, No. 4, Hal 564-582.

Fitriani, S, Raharjo dan Trimulyono, G. 2013. Aktivitas Antifungi Ekstrak Daun Kedondong (Spondias pinnata) dalam Menghambat Pertumbuhan Aspergillus niger. Jurnal Lentera Bio, Vol 2, No. 2, Hal 125-129
Georgiou, G Lin SC \& Sharma, MM, 1992, Surface Active Compounds From Microorganisms (Review). J. Biotechnol., No 10, Hal 60-65

Gmoser ,R, Jorge, A, Ferreira, Patrik R. Lennartsson dan Mohammad J. Taherzadeh. 2017. Filamentous Ascomycetes Fungi As A Source Of Natural Pigments. Journal Fungal Biology and Technology.

Gunawan, P. W., D. Ningsih, and M. Aprilia. 2010. Aktivitas Antibakteri dan Penyembuhan Luka Fraksi-fraksi Ekstrak Etanol Daun Kamboja (Plumeria acuminate Ait.) pada Kulit Kelinci yang Diinfeksi Staphylococcus aureus. J. Farmasi Indonesia, 7(2): 73-77

Hui, YH, 1996. Bailey's Industrial Oil and Fat Products. $5^{\text {th }}$ Edition Vol 5. New York

Hutasoit, S, I Ketut Suada \& I Gede Ketut Susrama. 2013. 'Uji Aktivitas Antijamur Ekstrak Beberapa Jenis Biota Laut terhadap Aspergillus flavus LINK dan Penicillium sp. LINK'. E-Jurnal Agroekoteknologi Tropika Vol. 2, No. 1

Ignacimuthu S, Arockiasamy S, Antonysmay M, Ravichandran P. 1999. Plant Regeneration Through Somatic Embryogenesis From Mature Leaf Explants Of Eryngium foetidum, a condiment. Journal of Plant cell, Tissue and Organ Culture 56: 131-137

Indrawijaya, Budhi. 2016. Formulasi Pestisida Nabati Minyak Mimba Menggunakan Surfaktan Dietanolamida Untuk Pengendalian Hama Ulat Grayak Pada Tanaman Kedelai. Tesis. IPB. Bogor.

Kubo I, K Fujita, K Nihei, A Kubo. 2004. AntiSalmonella Activity of (2E)-alkenals. Department of Environmental Science, Policy and Management, University of California, Berkeley

Mori, M, Aoyama, M, Doi, S, Kanethosi, A \& Hayashi, T, 1997, 'Antifungal Activity of Bark Extract of Deciduous Trees', Forestry Research, vol. 7, no 2, hal. $155-165$

Nugroho B H, 2010. Cara Membuat Media Tumbuh Dalam Pengembangan Massal APH Golongan Jamur. POPT BBP2TP, Surabaya. HIm. 1-5.

Oktaviana, Rahmawati dan Riza Linda, 2017. Aktivitas Antifungi Ekstrak Metanol Bunga Kamboja Putih (Plumeria acuminata) Terhadap Aspergilus clavatus. Jurnal Labora Medika Volume 1 No 2 Hal 22-29 
Rai, I.G.A. 2006. Aktivitas Fungisida Ekstrak Daun Saba (Piper majusculum) Terhadap Jamur Fusarium oxysporum Penyebab Penyakit Busuk Batang Panili. Tesis. Universitas Udayana.

Sari E M, Suwirmen, dan Zozi Aneloi Noli, 2014 Pengaruh Penggunaan Fungisida (Dithane M-45) Terhadap Pertumbuhan Tanaman Jagung (Zea mays L.) dan Kepadatan Spora Fungi Mikoriza Arbuskula (FMA). Jurnal Biologi Universitas Andalas (J. Bio. UA.)

Shavandi MA, Haddadian Z \& Ismail MHS, 2012, Eryngium foetidum L., Coriandrum sativum and Persicaria odorata L.: A review. J. Asian Sci. Res., 2: 410-426.

Sipahelut, Sophia Grace, 2015, Identifikasi Senyawa Antijamur Dari Minyak Daging Buah Pala Dan Aktivitasnya Terhadap Fusarium Moniliforme. Jurnal Agroforestri X Nomor 2

Syukriah, N., Liza, M. S., Harisun, Y., and Fadzillah, A. A. M. 2014. Effect of solvent extraction on antioxidant and antibacterial activities from Quercus infectoria (Manjakani). International Food Research Journal, 21(3): 1067-1073.

Thomson, W T. 1992. Agriculture Chemical. Books IV: Fungicides, Thompson Publication. Fresno, Calofornia. Page 153

Yanti N, Samingan dan Mudatisir. 2016. Uji Aktivitas Antifungi Ekstrak Etanol Gal manjakani (Quercus infectoria) Terhadap Candida albicans. Jurnal Ilmiah Mahasiswa Pendidikan Biologi Volume 1 Issue 1 Hal 1-9. 